\title{
Article \\ e-Commerce Sustainability: The Case of Pinduoduo in China
}

\author{
Younghoon Chang ${ }^{1}$, Siew Fan Wong ${ }^{2}$, Christian Fernando Libaque-Saenz ${ }^{3}$ \\ and Hwansoo Lee L,*(D) $^{4}$ \\ 1 School of Management and Economic, Beijing Institute of Technology, Beijing 100081, China \\ 2 Department of Computing and Information Systems, Sunway University, Bandar Sunway 47500, Malaysia \\ 3 Engineering Department, Universidad del Pacifico, Lima 11, Peru \\ 4 Department of Convergence Security, Dankook University, 152 Jukjeon-ro, Suji-gu, Yongin-si, \\ Gyeonggi-do 16890, Korea \\ * Correspondence: hanslee992@gmail.com
}

Received: 18 July 2019; Accepted: 25 July 2019; Published: 27 July 2019

check for updates

\begin{abstract}
Internet-based platforms are competing fiercely in the Chinese market by fostering an omni-channel shopping ecosystem. Companies have grouped under two giants, Alibaba and Tencent, leading to one-to-many competition dynamics in the Chinese market. In the midst of this competition, the three-year-old Pinduoduo has gained attention with its fast growth, positioning itself as the third biggest e-commerce platform in China with $19.4 \%$ of the market share. Pinduoduo has targeted a niche market made up of cheap products, low-income workers, and small business owners in small cities. Recently, however, many Pinduoduo users have returned to their former platforms, due to the proliferation of fake and low-quality products on the platform. Our study aims to investigate the reasons that prompted users to return to other platforms after their Pinduoduo experience. We conducted in-depth interviews to understand this phenomenon and built a research model based on risk theory and the customer resistance to change (CRC) framework. Results suggest that switching costs and relative attractiveness influence $C R C$, while risk perceptions form negative attitudes toward CRC, which finally result in negative word of mouth. Finally, theoretical and practical implications are discussed.
\end{abstract}

Keywords: consumer resistance to change; e-commerce; pinduoduo; product quality; word of mouth; China

\section{Introduction}

Competition between Internet platform providers has intensified in China, the world's biggest e-commerce market. The pressure for increasing the number of users and sales has led to an omni-channel shopping ecosystem in the market, encompassing all forms of online and offline channels. The Chinese e-commerce market today is divided between the giant Alibaba and the emerging challenger Tencent, each with its affiliates. Both sides are making aggressive moves to dominate the market through their own mobile messengers and customer resources. On the one hand, Alibaba now owns big department stores and supermarket chains with its recent affiliations, such as the Suning commerce group, which owns about 3000 offline electronics retail outlets across China. On the other hand, the second, third, and fourth biggest Chinese e-commerce providers, JD.com, Pinduoduo, and Vip.com, respectively, have joined Tencent, leading to one-to-many competition dynamics in the Chinese market. Although there still exists a significant gap in market shares between the first mover Alibaba and the challenger Tencent, this gap is considerably less than it was a few years ago. For example, during Guanggun Jie (which is the Single's day and China's biggest shopping day) on 
November 11, 2017, JD.com's gross sales matched those of Alibaba [1]. In addition, JD's own annual promotion on June 18 (6.18) achieved record sales equal to those on Single's day [2]. This situation was possible because Tencent provides a variety of support services for its affiliates through its major business models, WeChat and WeChat Pay, together with aggressive promotions, word of mouth (WOM), and discount strategies.

In the midst of competition, the new platform Pinduoduo has rapidly grown over the past years largely by capturing JD.com and Taobao users. Although less than three-years old, Pinduoduo has consolidated itself as the third biggest e-commerce platform in China. Pinduoduo now accounts for $5.7 \%$ of the market, and is catching up to JD.com's 25.2\% and the market leader Taobao's $55.0 \%$ [3]. From the beginning, Pinduoduo has positioned itself as a platform for cheap products. It strategically targets low-income workers and small business owners in small cities, occupying a niche market that is yet unconquered by Taobao and JD.com. A total of $64.7 \%$ of Pinduoduo users live in small and medium cities; this figure is only $50.2 \%$ for JD.com [3]. Furthermore, $61 \%$ of Pinduoduo users are in their 30s or younger, with relatively low incomes [3].

Recently, however, negative news and WOM about Pinduoduo have been spreading across social networks. Issues, such as fake products, low product quality, bad customer service, and excessive social pressures, have affected this platform [4]. As a result, many Pinduoduo users are returning to Taobao and JD.com. Figure 1, for example, shows that several users who uninstalled Pinduoduo in November 2017 moved to Taobao or JD.com the following month. In-depth interviews conducted in the preliminary research for our study corroborate this trend. Hence, assessing the factors that influence users' resistance to change e-commerce platforms is a critical issue for platform providers.

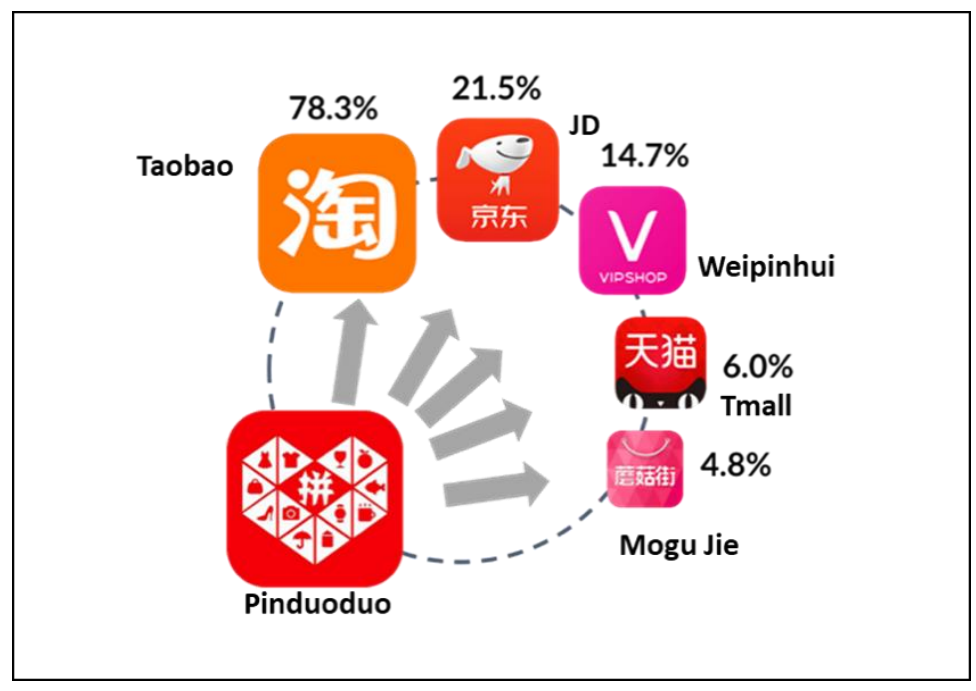

Figure 1. Common Apps installed in December 2017 for users who uninstalled Pinduoduo in November 2017 [5].

Various information systems and marketing studies have focused on customer churning and resistance to change [6-9]. Studies on resistance to change are largely classified into status quo bias research, which investigates why a certain group of customers continue to use existing technology, service, or product despite experiencing new options, and resistance to change research, which focuses on customers' resistance behavior in churning situations $[7,10]$. Our study aims to investigate the behavior of users and their reasons for returning to former e-commerce platforms after their experience on Pinduoduo. We established hypotheses and a research model based on risk theory [11], which is supported by the customer resistance to change (CRC) framework proposed by Kim and Gupta [7]. We used this framework to analyze risks and negative attitudes perceived by users when interacting with Pinduoduo. Our study took an empirical approach to explain customers' resistance to change in the Chinese e-commerce ecosystem based on CRC and risk theory. First, we conducted a qualitative study 
asking why users stopped using Pinduoduo and returned to their former e-commerce platforms. We particularly focused on returning Taobao and JD.com users who have tried using Pinduoduo. Second, a research model and hypotheses were established based on the findings derived from the qualitative study and then tested. Finally, we discussed the academic and practical implications of our study.

\section{Literature Review}

\subsection{China e-Commerce Market and Pinduoduo}

The Chinese e-commerce market is divided between the Alibaba and Tencent groups. Companies that used to be independent players are now joining the ecosystems of these titans to benefit from their economies of scale. These companies cross-invest in and acquire shares of each other to form strong alliances. Alibaba affiliates include the customer-to-customer (C2C) Taobao and the Taobao special offer edition, Tmall, Tmall Global, and SuningYigou. In addition, Alibaba is expanding its frontiers to include offline channels (e.g., freshhema.com, Taobao cafe) through the use of artificial intelligence, Internet of things (IoT), and big data analytics. Among Alibaba affiliates, Tmall and Tmall Global represent mid and high price ranges, while Taobao and Taobao special offer edition represent the mid-and-low-price market. In the case of Tencent affiliates, JD.com, Vip.com, and Pinduoduo target the mid-and-low-price market, and have launched omni-channel ecosystems using the boundaryless retail strategy. Recently, Tencent took over one of the big five Chinese supermarkets, Yonghui Superstores, and is strategically investing in the French supermarket chain Carrefour. It is currently transforming Yonghui Superstores into omni-channel shopping malls using its WeChat platform. JD.com has also started to follow this trend by opening an omni-channel shopping mall named 7fresh in Beijing (Figure 2).

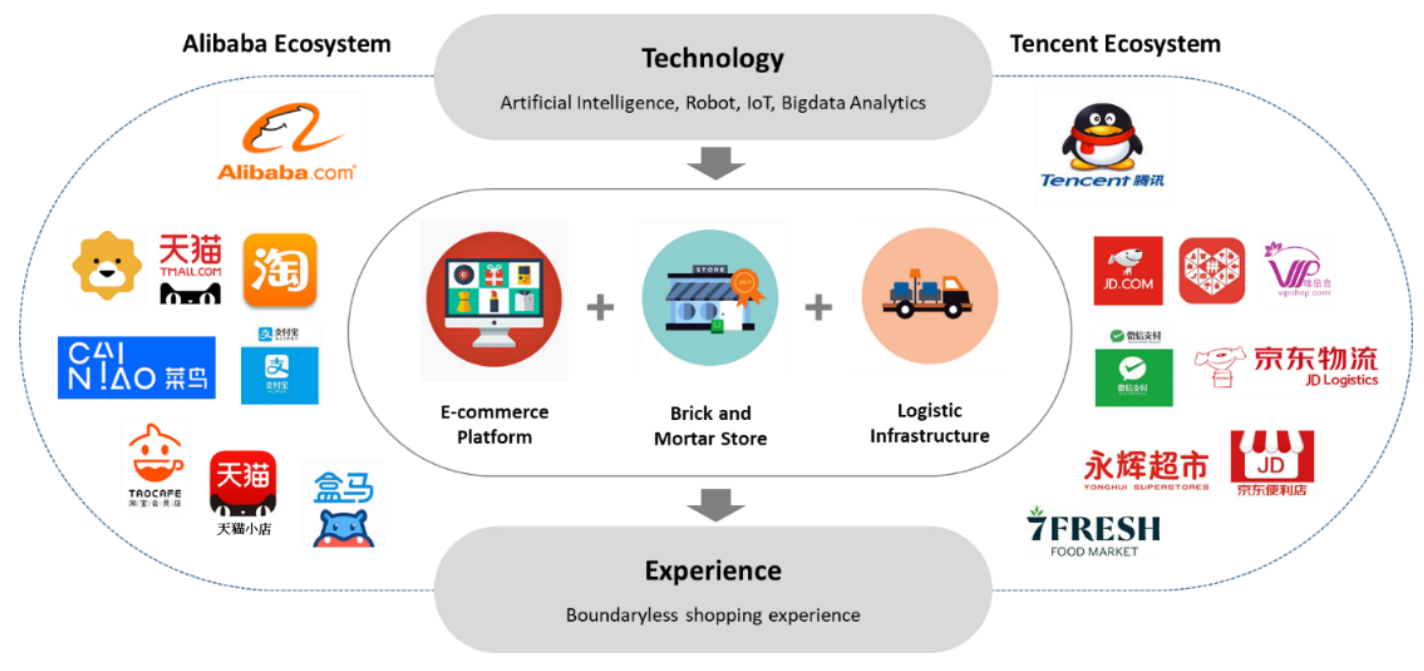

Figure 2. New retail and e-commerce ecosystems in China.

The Chinese e-commerce market is currently valued at US\$3.82 trillion, and in five years, the market value is projected to double [12]. The Chinese government's active consumption support policies and deregulations, in combination with a national population of 1.4 billion people, will boost this development. This development is also the result of pioneering logistics systems and marketing technologies of e-commerce companies realized through big data, artificial intelligence, and drone technologies. In addition, the mobile payment system, as the key means of e-commerce, is controlled by Alibaba and Tencent, thus leading to a significant customer attraction effect.

Former Google employee Colin Huang founded Pinduoduo, the third-largest Chinese e-commerce company (Figure 3), in October 2015 in Hangzhou, China. From the beginning, Pinduoduo strategically focused on the niche market where the two established Chinese e-commerce platforms (JD.com and 
Taobao) have not positioned themselves. It targets the young generation with low income looking for cheap products, as well as people who live in small-and-medium-sized tier 3 and tier 4 cities. It particularly focuses on the group buying function (Figure 4 for reference). Mr. Huang has actively used customer data from the beginning, analyzing customer preferences and needs in real-time. In collaboration with his partner WeChat, he conducted real-time analysis of conversations between customers and their requirements when performing group buying, and actively applied them to product planning, pricing, and shipping. The result was that this company, less than three years old, has joined the NASDAQ listings. As Pinduoduo's group buying function and low-price product sales have become successful, Taobao and JD.com have also started to introduce similar functions on their platforms. In addition, the media has recently highlighted Pinduoduo's problems concerning sales of fake products and shipping issues. Furthermore, customer demand for various favors, from their friends in group buying, has increased fatigue in interpersonal relationships [13,14]. Owing to these problems, many Pinduoduo users have migrated back to other platforms, such as Taobao and JD.com.

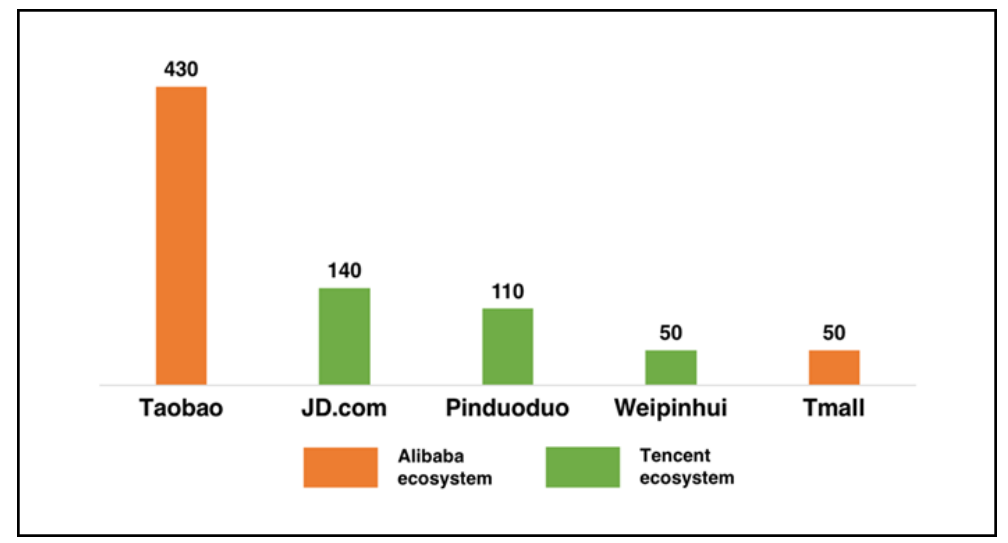

Figure 3. Largest Chinese e-commerce platforms by monthly active users (million, January 2018) (Source: Graziani [5]).

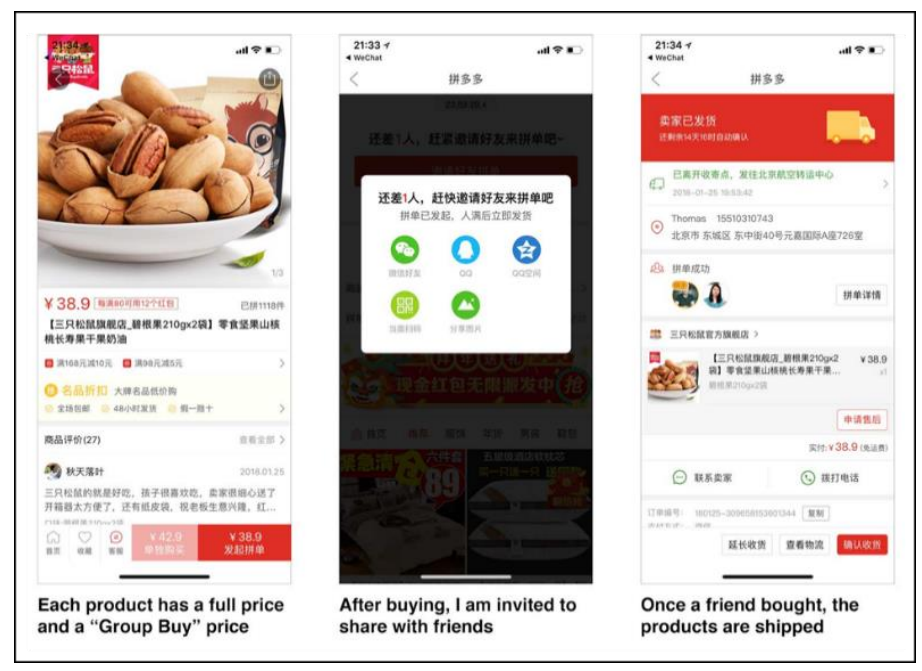

Figure 4. The group buying process in Pinduoduo.

\subsection{Customer Resistance to Change And Status Quo Bias Theory}

Resistance to change can be defined as an individual's unique, innate tendency to resist, or a resistant attitude acquired, due to certain causes [15]. This concept has been used in various studies in the area of information systems. These studies investigated mainly the resistance among organizational members to use information systems and the resistance behavior of customers in 
e-commerce platforms $[7,9,10]$. Kim and Gupta [7] discussed the tendency of online bookstore customers to continue using their current shopping platform and the refusal of existing customers to switch to a new environment or situation. Studies on resistance to using information systems in organizations defined 'resistance' behavior as users' low willingness to interact with a new system. These studies argued that the longer the existing system is used, the stronger will be the resistance to use of the new system [16]. This is understood as inertia, in which users who are locked in a specific system insist on using that system to reduce uncertainties associated with a new system.

Decision science explains the inertia among information system users using the status quo bias theory [17], which refers to the phenomenon in which users continue using the current product or service of their choice, or maintain a relationship with them [7,17]. The status quo bias is explained by two psychological mechanisms. The first one is loss aversion. When people evaluate an alternative, they feel that the cost of loss is greater than the potential profit or benefits they may gain through the change. Consequently, the psychological mechanism to maintain the status quo comes into play in case the profit or benefits of the alternative are not as great as those offered by the current option [7]. The second mechanism is regret aversion, in which people experience greater regret and feel responsible when they make a change through a specific behavior than when they stay in the status quo. To reduce psychological regret and responsibility, people must cope successfully with a change that brings uncertainties [7].

The characteristics and psychological mechanisms of status quo bias explain the resistance behavior in customers using a specific service. Kim and Gupta [7] introduced the theory of resistance to change and empirically demonstrated why online bookstore customers tend to continue using their current bookstores despite the availability of many other competing online stores. They demonstrated that resistance to change influences user intention to repurchase books at the current store, even if paying more. Kim, Chan and Lee [9] examined resistance to change in users of the Linux operating system. Using the technology acceptance model (TAM) and equity implementation model, they investigated the intention to accept an alternative operating system and found that the inertia to maintain the current operating system had a strong effect on user behavior.

Based on existing theories and research, our study investigated the user behavior of resisting the new, third-largest e-commerce platform provider and continuing to use the existing e-commerce platforms in a complex landscape where diverse e-commerce providers compete.

\subsection{Facets of Perceived Risk}

According to the literature on user acceptance and resistance behavior, one of the most important variables in users' decision making is risk $[18,19]$. Users who perceive risk under any circumstance have negative attitudes and behavior [11,20,21]. Peter and Ryan [22] defined perceived risk as "a kind of subjective expected loss," while Featherman and Pavlou [11] defined it as "the possible loss when pursuing a desired result." Since perceived risk has multidimensional attributes, Cunningham [23] divided it into performance risk and psychosocial risk. Performance risk is divided into economic, temporal, and effort, while psychosocial risk is classified into psychological and social risks (see Table 1). There are various studies on risk perception in the existing e-commerce literature, and it was found that several types of risks affect customer beliefs and attitudes toward e-commerce services [11,18,24]. In our study, we conducted a preliminary interview with customers. This qualitative approach improved our understanding of how users perceive risks when using Pinduoduo. Only the most mentioned risk factors in the interview were included in our research model. 
Table 1. Dimensions of perceived risk [11,18].

\begin{tabular}{cl}
\hline Dimension & \multicolumn{1}{c}{ Definition } \\
\hline Performance risk & $\begin{array}{l}\text { "The possibility of the product malfunctioning and not performing as it was } \\
\text { designed and advertised and therefore failing to deliver the desired } \\
\text { benefits." }\end{array}$ \\
\hline Social risk & $\begin{array}{l}\text { "Potential loss of status in one's social group as a result of adopting a } \\
\text { product or service, looking foolish or untrendy." }\end{array}$ \\
\hline Psychological risk & $\begin{array}{l}\text { "The risk that the selection or performance of the producer will have a } \\
\text { negative effect on the consumer's peace of mind or self-perception." }\end{array}$ \\
\hline Privacy risk & $\begin{array}{l}\text { "Potential loss of control over personal information, such as when } \\
\text { information about you is used without your knowledge or permission. The } \\
\text { extreme case is where a consumer is spoofed, meaning a criminal uses their } \\
\text { identity to perform fraudulent transactions." }\end{array}$ \\
\hline Financial risk & $\begin{array}{l}\text { "The probability that a purchase results in loss of money, as well as the } \\
\text { subsequent maintenance cost of the product." }\end{array}$ \\
\hline "Consumers may lose time when making a bad purchasing decision by \\
"Cime risk \\
$\begin{array}{l}\text { wasting time researching and making the purchase, learning how to use a } \\
\text { product or service only to have to replace it if it does not perform to } \\
\text { expectations." }\end{array}$
\end{tabular}

\subsection{Word of Mouth (WOM)}

WOM is defined as communication to exchange opinions and product and service information in people's social network $[25,26]$. In the information systems and communications field, scholars created the term electronic WOM (e-WOM) because people are now using the Internet to communicate with their social network members [27-29]. The WOM network includes everyone who connects to the Internet using computers or mobile phones. Research suggests that WOM is an important concept to understand a firm's reputation, sales generation, and consumer perception [30,31]. Kim, Chang, Wong and Park [31] found that satisfaction influences WOM positively, while dissatisfaction has a negative impact on WOM, in a group-buying social commerce context. In our study, we focused only on negative WOM because the risk is associated with negative belief. For example, Kim, Chang, Wong and Park [31] emphasized that consumers who are dissatisfied with a firm tend to warn other consumers about its services. They also try to spread their dissatisfaction using the Internet [32]. In addition, consumers tend to have high and strong motivation to spread WOM quickly when they have a negative perception of the service or firm [33]. In short, the more dissatisfied consumers are, the more they express their emotion in the form of negative WOM [34].

\subsection{Preliminary Research: In-Depth Interview}

We conducted in-depth interviews with current e-commerce users who had stopped using Pinduoduo. We first posted the interview request on WeChat Moments and asked them about the churning experience. If the respondents had experienced this change, we sent the full questionnaire to their WeChat Messenger. After the interview, we gave the participants 30 Yuan by WeChat Messenger. The questions were as follows: (a) What made you stop using Pinduoduo? (b) Why did you want to switch to another e-commerce platform? (c) Do you want to use Pinduoduo in the future? A total of nine respondents answered this questionnaire.

Most of the interviewees said that Pinduoduo's core problems were product quality and product authenticity. Moreover, product purchases from Pinduoduo were disturbed by various group-buying requests from friends and family, as well as advertisement in this platform. Based on the interview results, we have added perceived product quality as an antecedent to this phenomenon. Table 2 shows the detailed results of the interview. 
Table 2. Interview results.

\begin{tabular}{|c|c|c|c|}
\hline Interviewee Information & Previous Pinduoduo Experience & Current e-Commerce Platform & Interview Information \\
\hline Male, 21,1 st tier city & Yes & JD, Tmall & $\begin{array}{l}\text { I have ordered some stationaries from Pinduoduo, but they } \\
\text { lasted only a few days. Quality of products is terrible. }\end{array}$ \\
\hline Female, 35, 2nd tier city & Yes & Taobao, JD & $\begin{array}{l}\text { Too many group buying requests from friends and } \\
\text { relatives. Difficult to say no to others. Sometimes received } \\
\text { entirely different product and fake product. }\end{array}$ \\
\hline Female, 28,1 st tier city & Yes & JD & $\begin{array}{l}\text { When I am using Pinduoduo, people think I am a cheap } \\
\text { person. Also, I saw many fake products in Pinduoduo. I } \\
\text { am not going to buy anything from a platform that } \\
\text { sells counterfeit products. Also I got more spam calls after } \\
\text { using Pinduoduo. }\end{array}$ \\
\hline Female, 23, 3rd tier city & Yes & Taobao, Tmall, JD & $\begin{array}{l}\text { I bought a Korean cosmetic from Pinduoduo. It was not a } \\
\text { Korean brand but a fake brand. Also I got } \\
\text { skin trouble after using that cosmetic. I purchased this } \\
\text { cosmetic together with others and they all said that the } \\
\text { cosmetics have problems. I am not going to buy anything } \\
\text { together with those who have gave suggestion to purchase } \\
\text { this cosmetic. }\end{array}$ \\
\hline Male, 19,4 th tier city & Yes & JD, Taobao & $\begin{array}{l}\text { I used Pinduoduo several times. However, generally } \\
\text { speaking, it is full of fake brands and products. I was } \\
\text { thinking that it is targeting customers who want to buy } \\
\text { cheap products at a low price. I will tell other people to } \\
\text { never buy things from them. }\end{array}$ \\
\hline Male, 26, 3rd tier city & Yes & Taobao, Tmall & $\begin{array}{l}\text { I don't use the Wechat pay, and I want to accumulate Zhima } \\
\text { credit. I am also using finance service from Ant financial. } \\
\text { Pinduoduo doesn't provide these kinds of financial } \\
\text { services when we are buying the things. Also, don't have } \\
\text { many choices and full of fake products. }\end{array}$ \\
\hline
\end{tabular}


Table 2. Cont.

\begin{tabular}{|c|c|c|c|}
\hline Interviewee Information & Previous Pinduoduo Experience & Current e-Commerce Platform & Interview Information \\
\hline Female, 20, 1st tier city & Yes & Tmall, JD & $\begin{array}{l}\text { My mother asks me to use Pinduoduo, but this shopping } \\
\text { mall keeps on sending me Wechat messages. Also, many } \\
\text { people ask me to buy things together. Pinduoduo's } \\
\text { products are not as good as JD or Tmall. }\end{array}$ \\
\hline \multirow{2}{*}{ Male, 29, 2nd tier city } & \multirow{2}{*}{ Yes } & \multirow{2}{*}{ Taobao } & $\begin{array}{l}\text { They don't have many choices and there are } \\
\text { too many fake products. Cannot trust this company. }\end{array}$ \\
\hline & & & $\begin{array}{l}\text { Purchased some computer accessories before but they were } \\
\text { not working. }\end{array}$ \\
\hline \multirow{5}{*}{ Female, 24, 1st tier city } & \multirow{5}{*}{ Installed but never used } & \multirow{5}{*}{ JD, Tmall, VIPs } & $\begin{array}{l}\text { I have installed the app but never bought things from } \\
\text { Pinduoduo because I think it is very annoying. Although it } \\
\text { seems that we may purchase a product at a low price by } \\
\text { asking many of our friends to click the link and cut }\end{array}$ \\
\hline & & & down the rate, we help Pinduoduo to disseminate their \\
\hline & & & $\begin{array}{l}\text { products and promotion to our friends. In other words, } \\
\text { they publicize their products through their users at a little } \\
\text { cost!! In reality, the } \\
\text { price of the product we buy is still lower than the money }\end{array}$ \\
\hline & & & we finally pay for it!! So I will never buy products from \\
\hline & & & $\overline{\text { Pinduoduo. }}$ \\
\hline
\end{tabular}




\section{Research Model and Hypotheses}

\subsection{Perceived Product Quality}

Perceived product quality is an important issue for both producers and intermediaries (platform company) in the e-commerce industry [35]. Indeed, e-commerce platforms that sell authentic and good quality products will be trusted and are capable of building a good reputation in the market [36]. For instance, when JD.com entered the market, it tried to differentiate itself from Taobao.com by arguing that they would never sell fake and low-quality products. If they violated their own rule, they would compensate the customers by paying ten times more than what the customers have paid. Because of this differentiation strategy, JD.com quickly increased its market share in the Chinese e-commerce market. Therefore, perceived product quality does matter in China and to Chinese consumers.

Perceived product quality refers to "a consumer's judgment about the superiority or excellence of a product" [37]. It is a kind of attitude, and is related to satisfaction [38]. Kim and Gupta [7] suggested that even though satisfaction is an antecedent to CRC, it is not significant. Besides, in our in-depth interviews, several participants said that they had experienced lower product quality and received more fake products from Pinduoduo than they had through Taobao or JD.com. Therefore, we replaced the variable satisfaction with the construct perceived product quality as the antecedent to CRC. Previous research that focuses on product quality found this variable to influence customer loyalty, perceived value, emotion-related variables, and behavioral intention [35,38-40].

According to the status quo bias theory, consumers may be motivated to switch when they perceive unexpected negative results from a service or product. In contrast, they may be motivated to continue with the service or product when they have a positive perception $[7,17]$. Therefore, a consumer who experiences excellent product quality on an e-commerce platform will most likely maintain this relationship. Besides, according to the social exchange theory and Kim and Gupta [7]'s research, trust is formed when sellers or platforms perform in a proper manner that meets consumers' expectations. Accordingly, if a platform sells quality products, and consumers perceive this behavior, the platform will gain their trust. We hypothesize as follows:

Hypothesis 1: Product quality is positively related to consumer resistance to change.

Hypothesis 5: Product quality is positively related to trust.

\subsection{Trust}

Moorman et al. [41] defined trust as "the willingness of a party to be vulnerable to the actions of another party based on the expectation that the other will perform a particular action important to the trustor, irrespective of the ability to monitor or control that other party." Trust is the most important variable in many different academic fields. In marketing research, trust is the "cornerstone of long-term relationships with customers" [42], a key factor of relational commitment [43], and an essential element in building strong customer relationships and sustainable market share [44,45]. In the information systems field, e-commerce and privacy/security studies actively adopt this concept to examine the mechanism of building trust between trustees and trustors [46,47]. Liu et al. [48] suggested that trust strongly influences customers' behavioral intention and repeated purchase and recommendation to others in the e-commerce context. In the status quo bias theory, when customers feel in control, they want to stay with the current vendor [7]. Pavlou and Fygenson [49] suggested that trust has a role in controlling belief. Therefore, the longer users stay in a platform, and the more they purchase from it, the more they perceive this platform as trustworthy. Besides, a long-term positive relationship will lead to a unique switching cost, such as relational switching cost [50]. This relational switching cost consists of personal relationship loss and brand relationship loss [6]. In fact, when consumers like a specific brand or product, it is not easy to change it because consumers have already built personal 
and brand relationships. Therefore, when a platform is highly trusted, the switching costs tend to be high as well. Accordingly,

Hypothesis 2: Trust is positively related to user resistance to change.

Hypothesis 6: Trust is positively related to switching cost.

\subsection{Switching Cost}

Studies on switching cost have been mainly conducted in the field of marketing. Kim et al. [51] defined switching cost as the risk perception that customers feel when they try to change their service provider. Switching costs are divided into procedural, financial, and relational switching costs [50]. The higher the perception of costs, the greater the risk and burden that customers feel when they consider a conversion, resulting in a status quo bias and a lock-in effect on the current platform. Even if alternatives are attractive, and there are switching benefits, there is a tendency to maintain the current platform, due to increased uncertainty $[7,51,52]$. As a result, switching costs are the cause of loss and regret avoidance, which are psychological mechanisms of the status quo bias. That is, when customers consider switching to another company, they prefer to maintain the current provider and resist switching to other options [6,7]. Therefore,

Hypothesis 3: Switching cost is positively related to consumer resistance to change.

\subsection{Relative Attractiveness}

In competition, especially in the technology-based and e-commerce sectors, relative advantage is a critical factor for the firm to succeed in the market. Rogers [53] also emphasized that relative advantage is a core factor in innovation diffusion theory. Similar to relative advantage, in marketing and e-commerce research, there is a construct named relative attractiveness. Kim and Gupta [7] defined relative attractiveness as "the customer perception of the attractiveness of shopping with the current online vendor in comparison with other online vendors." In China, today, there are hundreds of e-commerce platforms in business. In this kind of fierce competition, it is difficult for platforms to survive and rule the market. These days, consumers are smart, and they will not stay and purchase things from a platform without relative attractiveness [54]. Kim and Gupta [7] also verified that relative attractiveness strongly influences $C R C$, which motivates users to stay on the current platform. If the current platform provides relative attractiveness, consumers will perceive this as a benefit. If consumers think the benefits from a platform are higher than those offered by other platforms, they will perceive high switching costs $[7,9]$. We hypothesize as follows:

Hypothesis 4: Relative attractiveness is positively related to consumer resistance to change.

Hypothesis 7: Relative attractiveness is positively related to switching costs.

\subsection{Antecedents of Negative Attitude: Psychology Risk, Social Risk, Privacy Risk}

Perceived risk is a strong antecedent to consumers' behavioral beliefs, attitude, and intention in various information systems contexts $[11,51,55]$. Prior research found that the higher the perception of 
risk, the more negative is its influence on beliefs, attitude, intention, and actual behavior. In our study, we focused on three facets of perceived risk. First, psychological risk refers to "the risk that the selection or performance of the producer will have a negative effect on the consumer's peace of mind or self-perception" [11]. Second, social risk refers to a "potential loss of status in one's social group as a result of adopting a product or service, looking foolish or untrendy" [11]. Third, privacy risk refers to a "potential loss of control over personal information, such as when information about you is used without your knowledge or permission. The extreme case is where a consumer is 'spoofed' meaning a criminal uses their identity to perform fraudulent transactions" [11]. Through the in-depth interviews, we found that respondents perceived all three kinds of risks when using Pinduoduo. According to Lee [18], various facets of risk strongly influence attitude toward online banking services. Therefore, we expect that as the three mentioned facets of risk increase, negative attitude will increase as well.

Hypothesis 8: Psychology risk is positively related to negative attitude.

Hypothesis 9: Social risk is positively related to negative attitude.

Hypothesis 10: Privacy risk is positively related to negative attitude.

\subsection{Attitude, CRC, and WOM}

Attitude refers to "an accumulation of information about an object, person, situation or experience ... a predisposition to act in a positive or negative way toward some object" [56]. It is "essentially information we have obtained about someone or something that we form an opinion or predisposition about" ([57]. Attitude is a strong antecedent to behavioral intention and actual behavior [58]. When consumers form a negative attitude, it will affect both the CRC and negative WOM because it will negatively impact consumer behavior [9]. In our study, CRC refers to the resistance of a consumer to use an e-commerce platform (Kim et al., 2014). In the e-commerce context, customers spread negative WOM when they are dissatisfied with the product or service they have purchased [31]. Wangenheim and Bayon [59] also found that users who decide to stay on a platform and never, or not for a long time, churned to other options tend to make more WOM about the company they decided to continue using. In our study, a consumer who returned to Alibaba or JD.com after experiencing Pinduoduo would spread negative WOM about Pinduoduo because Pinduoduo had given them unhappy and dissatisfied experiences. Figure 5 shows the research model of this study

Hypothesis 11: Negative attitude is positively related to negative WOM.

Hypothesis 12: Negative attitude is positively related to consumer resistance to change.

Hypothesis 13: Consumer resistance to change is positively related to negative WOM. 

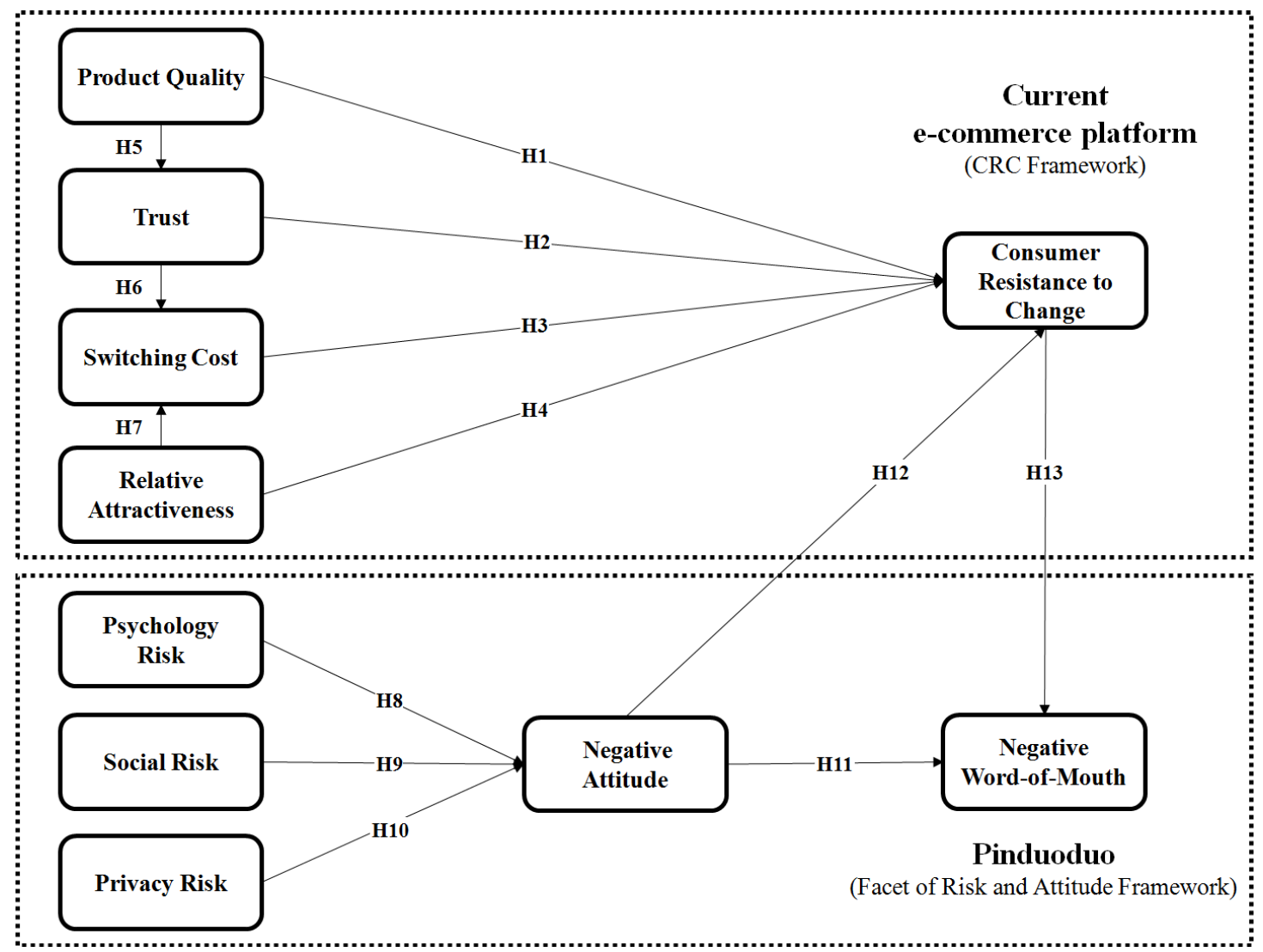

Figure 5. Research model.

\section{Research Methodology}

\subsection{Research Procedure}

Nine e-commerce users were interviewed to consider the variables included in our research model. The research model and hypotheses were tested using questionnaires that were distributed to e-commerce users. The reliability and validity of the latent variables were verified before the hypothesis testing. The research model and hypothesis assessment were conducted using the partial least squares structural equation modeling (PLS-SEM) analytical technique, which maximizes predictive power while minimizing the prediction error between the latent and measured variables [60]. In addition, this technique allows researchers to conduct a meaningful analysis even when the sample size is relatively small (Henseler et al., 2016).

\subsection{Measurement Development}

All the measurement items were adopted from previous research and modified to fit our research context. Three questions on product quality were adapted from Wells et al. [61]. Five items on trust, five on switching costs, and four on relative attractiveness were adapted from Kim and Gupta [7]. Psychological, social, and privacy risk items were adapted from Featherman and Pavlou [11]. Two items on negative WOM were adapted from Kim, Kim and Kim [30] and Kim, Chang, Wong and Park [31]. For CRC, we adapted items from Pritchard et al. [62]. Four items on negative attitude were adapted from Ha et al. [63]. Table 3 shows the measurement items and their references. 
Table 3. Measurement items.

\begin{tabular}{|c|c|c|}
\hline Construct & Items & Reference \\
\hline Product Quality (PQ) & $\begin{array}{l}\text { PQ1: I perceive the PRODUCTS offered at the e-commerce platform (Taobao/Tmall/JD) to be } \\
\text { more durable than those offered by Pinduoduo } \\
\text { PQ2: The e-commerce platform (Taobao/Tmall/JD) PRODUCTS appear to me to be better } \\
\text { packaged than Pinduoduo. } \\
\text { PQ3: I perceive the PRODUCTS offered at the e-commerce platform (Taobao/Tmall/JD) to be } \\
\text { of higher quality than those offered by Pinduoduo }\end{array}$ & Wells, Valacich and Hess [61] \\
\hline Trust (TRS) & $\begin{array}{l}\text { TRS1: The e-commerce platform that I am using now (Taobao/Tmall/JD) keeps its promises } \\
\text { and commitment } \\
\text { TRS2: The e-commerce platform that I am using now (Taobao/Tmall/JD) can be relied upon } \\
\text { TRS3: The e-commerce platform that I am using now (Taobao/Tmall/JD) cares about its } \\
\text { customers } \\
\text { TRS4: The e-commerce platform that I am using now (Taobao/Tmall/JD) is capable of doing } \\
\text { its job } \\
\text { TRS5: The e-commerce platform that I am using now (Taobao/Tmall/JD) is trustworthy }\end{array}$ & Kim and Gupta [7] \\
\hline $\begin{array}{l}\text { Switching } \\
\text { Costs (SWC) }\end{array}$ & $\begin{array}{l}\text { SWC1: It would take more time and effort to switch my shopping activities from here } \\
\text { (Taobao/Tmall/JD) to Pinduoduo } \\
\text { SWC2: Switching my shopping activities from here (Taobao/Tmall/JD) to Pinduoduo would } \\
\text { result in some unexpected hassle } \\
\text { SWC3: It would be a hassle for me to switch my shopping activities from here } \\
\text { (Taobao/Tmall/JD) to Pinduoduo } \\
\text { SWC4: The costs in time, money, and effort to switch my shopping activities from here } \\
\text { (Taobao/Tmall/JD) to Pinduoduo are high } \\
\text { SWC5: All things considered, I would lose a lot if I were to switch my shopping activities } \\
\text { from here (Taobao/Tmall/JD) to Pinduoduo }\end{array}$ & Kim and Gupta [7] \\
\hline Relative Attractiveness (REL) & $\begin{array}{l}\text { REL1: Compared to shopping at Pinduoduo, the e-commerce platform that I am using now } \\
\text { (Taobao/Tmall/JD) would be more advantageous to me } \\
\text { REL2: Compared to shopping at Pinduoduo, the e-commerce platform that I am using now } \\
\text { (Taobao/Tmall/JD) would be more appealing to me } \\
\text { REL3: Compared to shopping at Pinduoduo, the e-commerce platform that I am using now } \\
\text { (Taobao/Tmall/JD) would be more satisfactory to me } \\
\text { REL4: Overall, it would be better for me to shop from the e-commerce platform that I am } \\
\text { using now (Taobao/Tmall/JD) than from Pinduoduo }\end{array}$ & Kim and Gupta [7] \\
\hline
\end{tabular}


Table 3. Cont.

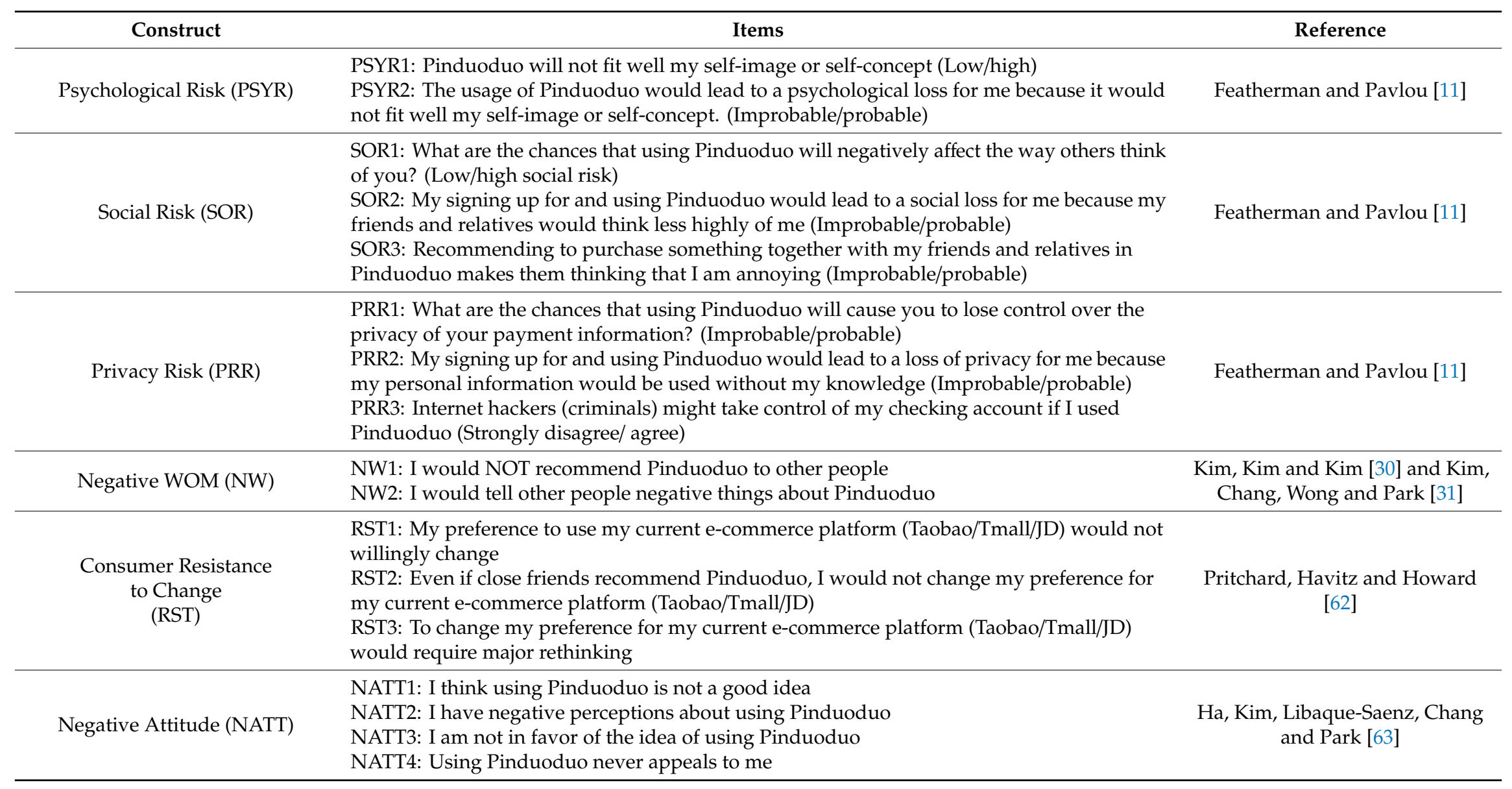




\subsection{Research Sample}

Questionnaires with 58 items, including demographic questions, were distributed to students in a large university in Guangdong province, China. The respondents had experienced Pinduoduo and other e-commerce platforms. We used the free online survey platform WJX.com to collect the data. After the respondents completed the survey, we gave them a gift coupon. A total of 214 responses were collected, and 203 valid responses were included in the final analysis; responses with missing values or invalid answers were excluded. The percentage of students in their 20 s was relatively high among the respondents. Gender, income level, e-commerce usage patterns were evenly distributed. The detailed sample characteristics are shown in Table 4.

Table 4. Characteristics of the respondents.

\begin{tabular}{|c|c|c|c|}
\hline \multicolumn{2}{|c|}{ Category } & \multirow{2}{*}{$\frac{\text { Number }}{96}$} & \multirow{2}{*}{$\begin{array}{l}\text { Ratio } \\
47.29 \%\end{array}$} \\
\hline \multirow{2}{*}{ Gender } & Male & & \\
\hline & Female & 107 & $52.71 \%$ \\
\hline \multirow{4}{*}{ Age } & Below 20 & 34 & $16.75 \%$ \\
\hline & $21 \sim 30$ & 154 & $75.86 \%$ \\
\hline & $31 \sim 40$ & 4 & $1.97 \%$ \\
\hline & 40 above & 11 & $5.42 \%$ \\
\hline \multirow{3}{*}{ Job } & Student & 152 & $74.88 \%$ \\
\hline & White collar worker & 35 & $17.24 \%$ \\
\hline & Etc. & 16 & $7.88 \%$ \\
\hline \multirow{5}{*}{ Family Income } & Under 10,000 Yuan & 62 & $30.54 \%$ \\
\hline & $10,001 \sim 20,000$ & 49 & $24.14 \%$ \\
\hline & $20,001 \sim 30,000$ & 30 & $14.78 \%$ \\
\hline & $30,001 \sim 50,000$ & 16 & $7.88 \%$ \\
\hline & Over 50,000 & 46 & $22.66 \%$ \\
\hline \multirow{5}{*}{$\begin{array}{l}\text { Number of e-commerce } \\
\text { platform in use }\end{array}$} & 1 & 13 & $6.40 \%$ \\
\hline & 2 & 74 & $36.45 \%$ \\
\hline & 3 & 69 & $33.99 \%$ \\
\hline & 4 & 28 & $13.79 \%$ \\
\hline & 5 & 19 & $9.36 \%$ \\
\hline \multirow{5}{*}{$\begin{array}{l}\text { Amount of money spent } \\
\text { on e-commerce in a week }\end{array}$} & Less than 100 yuan & 44 & $21.67 \%$ \\
\hline & $100 \sim 500$ & 108 & $53.20 \%$ \\
\hline & $501 \sim 1000$ & 22 & $10.84 \%$ \\
\hline & $1001 \sim 3000$ & 18 & $8.87 \%$ \\
\hline & More than 3000 yuan & 11 & $5.42 \%$ \\
\hline
\end{tabular}

\section{Data Analysis and Results}

\subsection{Reliability and Validity of Our Measurement Model}

Our measurement model was evaluated with reliability, convergent validity, and discriminant validity tests. When Cronbach's alpha is over 0.6 , the construct is judged to be reliable [64]. Rho $(\rho \mathrm{A})$ is also used to assess reliability, and it is recommended that it should be over 0.7. Cronbach's alpha and $\rho$ A values of all constructs in our study were found to be more than 0.7 , and thus the items are reliable. Convergent validity can be evaluated using the factor loading score of each item, composite reliability 
(CR), and averaged variance extracted (AVE) [65]. The factor loading score should be statistically significant and larger than 0.5. The cut-off valued for CR and AVE is 0.7 and 0.8 , respectively. As shown in Table 5, all criteria for reliability and convergent validity were satisfactory.

Table 5. Reliability and convergent validity.

\begin{tabular}{|c|c|c|c|c|c|c|c|}
\hline Construct & Items & Loading & $\begin{array}{c}\text { Mean } \\
(\text { STDEV) }\end{array}$ & $\begin{array}{c}\text { Cronbach's } \\
\text { Alpha }\end{array}$ & rho_A & $\begin{array}{l}\text { Composite } \\
\text { Reliability }\end{array}$ & AVE \\
\hline \multirow{3}{*}{$P Q$} & PQ1 & 0.92 & $5.79(1.28)$ & \multirow{3}{*}{0.87} & \multirow{3}{*}{0.88} & \multirow{3}{*}{0.92} & \multirow{3}{*}{0.80} \\
\hline & PQ2 & 0.85 & $5.51(1.38)$ & & & & \\
\hline & PQ3 & 0.91 & $5.91(1.29)$ & & & & \\
\hline \multirow{5}{*}{ TRS } & TRS1 & 0.89 & $5.79(1.11)$ & \multirow{5}{*}{0.94} & \multirow{5}{*}{0.94} & \multirow{5}{*}{0.95} & \multirow{5}{*}{0.80} \\
\hline & TRS2 & 0.91 & $5.73(1.10)$ & & & & \\
\hline & TRS3 & 0.89 & $5.66(1.10)$ & & & & \\
\hline & TRS4 & 0.90 & $5.78(1.12)$ & & & & \\
\hline & TRS5 & 0.90 & $5.68(1.13)$ & & & & \\
\hline \multirow{5}{*}{ SWC } & SWC1 & 0.81 & $5.91(1.14)$ & \multirow{5}{*}{0.91} & \multirow{5}{*}{0.91} & \multirow{5}{*}{0.93} & \multirow{5}{*}{0.73} \\
\hline & SWC2 & 0.88 & $5.87(1.14)$ & & & & \\
\hline & SWC3 & 0.89 & $5.82(1.20)$ & & & & \\
\hline & SWC4 & 0.88 & $5.56(1.18)$ & & & & \\
\hline & SWC5 & 0.81 & $5.36(1.39)$ & & & & \\
\hline \multirow{4}{*}{ REL } & REL1 & 0.80 & $6.12(1.23)$ & \multirow{4}{*}{0.91} & \multirow{4}{*}{0.92} & \multirow{4}{*}{0.94} & \multirow{4}{*}{0.79} \\
\hline & REL2 & 0.90 & $6.25(1.14)$ & & & & \\
\hline & REL3 & 0.92 & $6.22(1.11)$ & & & & \\
\hline & REL4 & 0.92 & $6.16(1.12)$ & & & & \\
\hline \multirow{2}{*}{ PSYR } & PSYR1 & 0.96 & $5.38(1.66)$ & \multirow{2}{*}{0.91} & \multirow{2}{*}{0.92} & \multirow{2}{*}{0.96} & \multirow{2}{*}{0.92} \\
\hline & PSYR2 & 0.95 & $4.93(1.77)$ & & & & \\
\hline \multirow{3}{*}{ SOR } & SOR1 & 0.88 & $4.46(1.81)$ & \multirow{3}{*}{0.85} & \multirow{3}{*}{0.85} & & \\
\hline & SOR2 & 0.92 & $4.00(2.01)$ & & & 0.91 & 0.77 \\
\hline & SOR3 & 0.83 & $5.04(1.83)$ & & & & \\
\hline & PRR1 & 0.92 & $4.43(1.59)$ & & & & \\
\hline PRR & PRR2 & 0.92 & $4.55(1.61)$ & 0.90 & 0.90 & 0.94 & 0.84 \\
\hline & PRR3 & 0.90 & $4.20(1.67)$ & & & & \\
\hline & RST1 & 0.79 & $5.58(1.10)$ & & & & \\
\hline RST & RST2 & 0.91 & $5.55(1.15)$ & 0.82 & 0.84 & 0.89 & 0.73 \\
\hline & RST3 & 0.87 & $5.48(1.19)$ & & & & \\
\hline & NATT1 & 0.95 & $5.20(1.70)$ & & & & \\
\hline & NATT2 & 0.95 & $5.26(1.72)$ & 0.96 & 0.96 & 0.97 & 0.89 \\
\hline NATT & NATT3 & 0.96 & $5.11(1.75)$ & & & & \\
\hline & NATT4 & 0.92 & $5.57(1.60)$ & & & & \\
\hline NW & NW1 & 0.96 & $5.30(1.87)$ & 0.90 & 0.90 & 0.95 & 0.91 \\
\hline & NW2 & 0.95 & $4.69(1.91)$ & & & & \\
\hline
\end{tabular}

Note: Product Quality (PQ), Trust (TRS), Switching Costs (SWC), Relative Attractiveness (REL), Psychological Risk (PSYR), Social Risk (SOR), Privacy Risk (PRR), Negative WOM (NW), Consumer Resistance to Change (RST), Negative Attitude (NATT). 
As for discriminant validity, we used the methods proposed by Fornell and Larcker [65] and Henseler et al. [66]. According to Fornell and Larcker [65], to ensure discriminant validity, the values of the square root of AVEs should be higher than the correlations with other constructs. Henseler, Hubona and Ray [66] introduced the heterotrait-monotrait ratio (HTMT) by highlighting the limitations of Fornell and Larcker [65]'s method. It is recommended that the HTMT ratio should not exceed 0.85 . As shown in Table 6, all the square roots of AVEs were higher than other inner correlations, while the maximum HTMT ratio was 0.78 . Both criteria were satisfied; therefore, discriminant validity was confirmed.

Table 6. Discriminant validity.

\begin{tabular}{|c|c|c|c|c|c|c|c|c|c|c|}
\hline & PQ & TRS & SWC & REL & PSYR & SOR & PRR & RST & NATT & NW \\
\hline PQ & 0.89 & & & & & & & & & \\
\hline TRS & $\begin{array}{c}0.56 \\
(0.62)\end{array}$ & 0.90 & & & & & & & & \\
\hline SWC & $\begin{array}{c}0.64 \\
(0.72)\end{array}$ & $\begin{array}{c}0.51 \\
(0.55)\end{array}$ & 0.85 & & & & & & & \\
\hline REL & $\begin{array}{c}0.65 \\
(0.73)\end{array}$ & $\begin{array}{c}0.45 \\
(0.48)\end{array}$ & $\begin{array}{c}0.52 \\
(0.58)\end{array}$ & 0.89 & & & & & & \\
\hline PSYR & $\begin{array}{c}0.53 \\
(0.59)\end{array}$ & $\begin{array}{c}0.28 \\
(0.30)\end{array}$ & $\begin{array}{c}0.46 \\
(0.50)\end{array}$ & $\begin{array}{c}0.44 \\
(0.48)\end{array}$ & 0.96 & & & & & \\
\hline SOR & $\begin{array}{c}0.35 \\
(0.40)\end{array}$ & $\begin{array}{c}0.15 \\
(0.17)\end{array}$ & $\begin{array}{c}0.37 \\
(0.42)\end{array}$ & $\begin{array}{c}0.37 \\
(0.41)\end{array}$ & $\begin{array}{c}0.61 \\
(0.70)\end{array}$ & 0.88 & & & & \\
\hline PRR & $\begin{array}{c}0.28 \\
(0.32)\end{array}$ & $\begin{array}{c}0.15 \\
(0.16)\end{array}$ & $\begin{array}{c}0.38 \\
(0.41)\end{array}$ & $\begin{array}{c}0.24 \\
(0.27)\end{array}$ & $\begin{array}{c}0.50 \\
(0.55)\end{array}$ & $\begin{array}{c}0.60 \\
(0.68)\end{array}$ & 0.92 & & & \\
\hline RST & $\begin{array}{c}0.45 \\
(0.54)\end{array}$ & $\begin{array}{c}0.36 \\
(0.42)\end{array}$ & $\begin{array}{c}0.51 \\
(0.59)\end{array}$ & $\begin{array}{c}0.47 \\
(0.54)\end{array}$ & $\begin{array}{c}0.41 \\
(0.47)\end{array}$ & $\begin{array}{c}0.33 \\
(0.39)\end{array}$ & $\begin{array}{c}0.35 \\
(0.41)\end{array}$ & 0.86 & & \\
\hline NATT & $\begin{array}{c}0.57 \\
(0.63)\end{array}$ & $\begin{array}{c}0.33 \\
(0.34)\end{array}$ & $\begin{array}{c}0.51 \\
(0.55)\end{array}$ & $\begin{array}{c}0.44 \\
(0.47)\end{array}$ & $\begin{array}{c}0.66 \\
(0.70)\end{array}$ & $\begin{array}{c}0.58 \\
(0.63)\end{array}$ & $\begin{array}{c}0.45 \\
(0.48)\end{array}$ & $\begin{array}{c}0.50 \\
(0.56)\end{array}$ & 0.94 & \\
\hline NW & $\begin{array}{c}0.49 \\
(0.56)\end{array}$ & $\begin{array}{c}0.34 \\
(0.38)\end{array}$ & $\begin{array}{c}0.47 \\
(0.52)\end{array}$ & $\begin{array}{c}0.43 \\
(0.47)\end{array}$ & $\begin{array}{c}0.52 \\
(0.57)\end{array}$ & $\begin{array}{c}0.45 \\
(0.51)\end{array}$ & $\begin{array}{c}0.43 \\
(0.48)\end{array}$ & $\begin{array}{c}0.48 \\
(0.55)\end{array}$ & $\begin{array}{c}0.72 \\
(0.78)\end{array}$ & 0.95 \\
\hline
\end{tabular}

Note: Product Quality (PQ), Trust (TRS), Switching Costs (SWC), Relative Attractiveness (REL), Psychological Risk (PSYR), Social Risk (SOR), Privacy Risk (PRR), Negative WOM (NW), Consumer Resistance to Change (RST), Negative Attitude (NATT).

This study collected data through self-reporting, so there is a possibility that common method bias (CMB) problems exist [67]. Various methods have been introduced to address CMB issues, with Kock and Lynn [68]'s approach (full collinearity test) known to be highly reliable. To assess CMB, the variance inflation factor (VIF) from the full collinearity test should be less than 3.3. In this study, the maximum value of VIF was 2.62, so CMB was not a significant issue.

\subsection{Hypothesis Testing Results}

In order to verify the proposed hypotheses, a bootstrap re-sampling $(\mathrm{N}=1000)$ technique was applied, and the significance of each hypothesis was verified. According to the results, all hypotheses, except hypotheses 1,2, and 10, were statistically significant. The influence of switching costs on consumer resistance to change was statistically significant $(\mathrm{H} 3$ : Path coefficient $=0.25$; $\mathrm{t}$-value $=2.752$; $\mathrm{p}<0.01)$ and the influence of relative attractiveness was also significant $(\mathrm{H} 4$ : Path coefficient $=0.21$ $\mathrm{t}$-value $=2.05, \mathrm{p}<0.05$ ). H5 (Product Quality $\rightarrow$ Consumer Resistance to Change), H6 (Trust $\rightarrow$ Switching Costs), and H7 (Relative Attractiveness $\rightarrow$ Switching Costs) were all significant at the $99.9 \%$ confidence level (H5: Path coefficient $=0.56$; $\mathrm{t}$-value $=9.34 ; \mathrm{p}<0.001, \mathrm{H} 6$ : Path coefficient $=0.34$; $\mathrm{t}$-value $=5.18 ; \mathrm{p}<0.001$, H7: Path coefficient $=0.37 ; \mathrm{t}$-value $=6.06 ; \mathrm{p}<0.001)$. Psychology risk and social risk were significant predictors of negative attitudes, while the relationship between privacy risk 
and negative attitude was not significant (H8: Path coefficient $=0.47$; $\mathrm{t}$-value $=6.16 ; \mathrm{p}<0.001, \mathrm{H} 9$ : Path coefficient $=0.25 ; \mathrm{t}$-value $=2.90 ; \mathrm{p}<0.01$ ). Negative attitude strongly influenced negative WOM and consumer resistance to change (H11: Path coefficient $=0.64$; $\mathrm{t}$-value $=11.28 ; \mathrm{p}<0.001$, H12: Path coefficient $=0.28 ; \mathrm{t}$-value $=4.24 ; \mathrm{p}<0.001$ ). Consumer resistance to change also had a statistically significant impact on negative WOM (H13: Path coefficient $=0.16$; $\mathrm{t}$-value $=3.39 ; \mathrm{p}<0.001)$. The $\mathrm{R}$-squared of negative attitude, consumer resistance to change, and negative WOM were $48.3 \%, 37.1 \%$, and $54.4 \%$, respectively (see Figure 6 and Table 7 ).

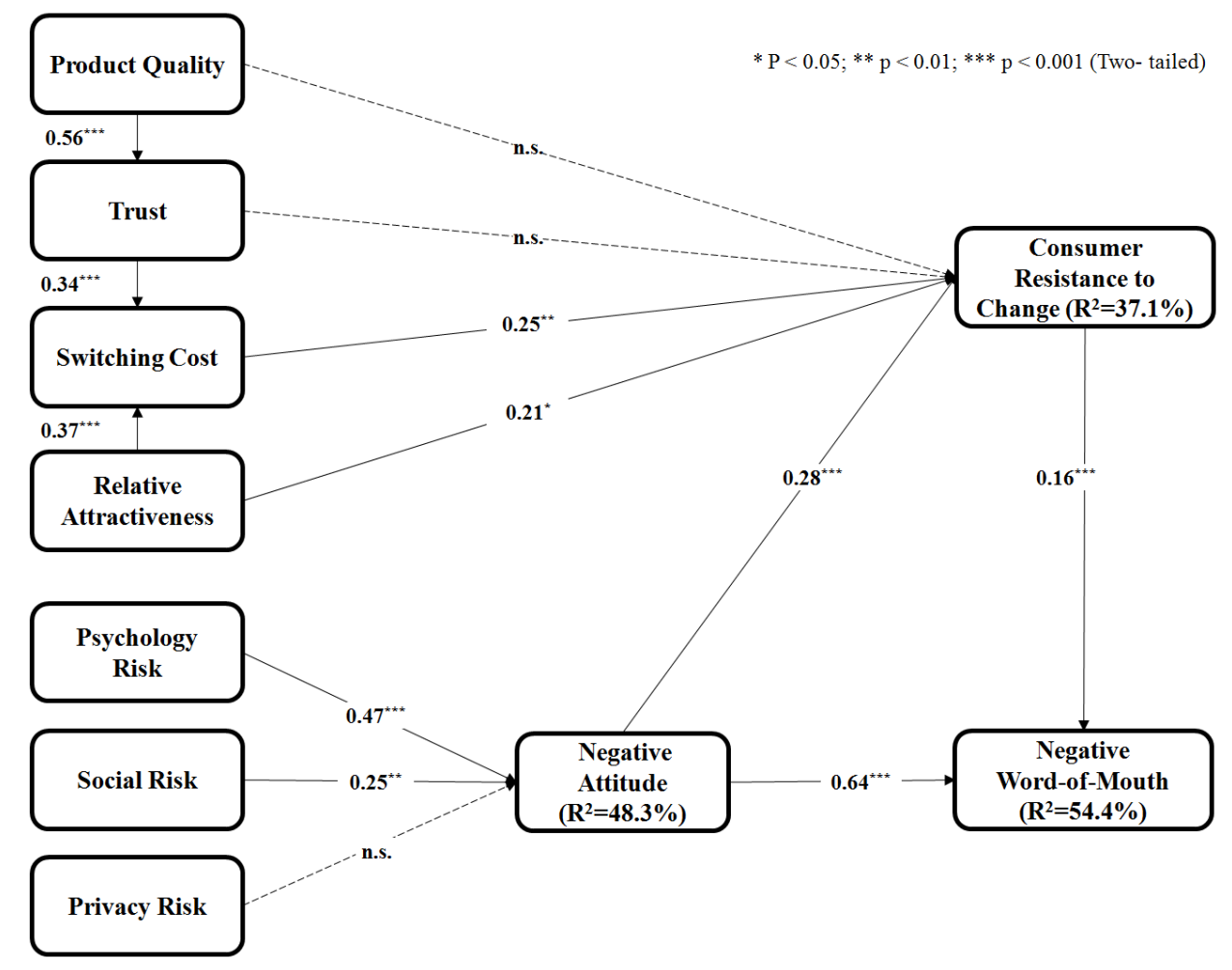

Figure 6. Hypotheses testing results.

Table 7. Summary of Hypotheses testing results.

\begin{tabular}{crccc}
\hline & Hypotheses & P. C. & $t$ & Result \\
\hline H1 & Product Quality $\rightarrow$ Consumer Resistance to Change & 0.04 & 0.42 & Rejected \\
\hline H2 & Trust $\rightarrow$ Consumer Resistance to Change & 0.07 & 0.10 & Rejected \\
\hline H3 & Switching Cost $\rightarrow$ Consumer Resistance to Change & 0.25 & 2.75 & Supported \\
\hline H4 & Relative Attractiveness $\rightarrow$ Consumer Resistance to Change & 0.21 & 2.05 & Supported \\
\hline H5 & Product Quality $\rightarrow$ Trust & 0.56 & 9.34 & Supported \\
\hline H6 & Trust $\rightarrow$ Switching Cost & 0.34 & 5.18 & Supported \\
\hline H7 & Relative Attractiveness $\rightarrow$ Switching Cost & 0.37 & 6.06 & Supported \\
\hline H8 & Psychology Risk $\rightarrow$ Negative Attitude & 0.47 & 6.16 & Supported \\
\hline H9 & Social Risk $\rightarrow$ Negative Attitude & 0.25 & 2.91 & Supported \\
\hline H10 & Privacy Risk $\rightarrow$ Negative Attitude & 0.07 & 0.97 & Rejected \\
\hline H11 & Negative Attitude $\rightarrow$ Negative Word-of-Mouth & 0.64 & 11.28 & Supported \\
\hline H12 & Negative Attitude $\rightarrow$ Consumer Resistance to Change & 0.28 & 4.24 & Supported \\
\hline H13 & Consumer Resistance to Change $\rightarrow$ Negative Word-of-Mouth & 0.16 & 3.39 & Supported \\
\hline & Note: Path coefficient (P. C.). & & &
\end{tabular}


The PLS-SEM study requires a report on the goodness of fit (GoF) of the model. The recommended cut-off value of GoF is 0.36 for a sufficient model fit [69]. Our model had a GoF equal to 0.62. Therefore, our research model is structurally appropriate.

\section{Discussion and Implications}

\subsection{Discussion of Findings}

Our results offer some interesting implications. First, switching cost and relative attractiveness have statistically significant effects on consumer resistance to change (CRC). Several existing studies have empirically demonstrated the relationship between switching cost and CRC [70]. They concluded that the effect of switching costs on CRC is weaker than the effect of other factors. However, the results of our study suggest that switching costs have a stronger effect on CRC than relative attractiveness, which is considered a characteristic of e-commerce. Essentially, there is no major difference between e-commerce platforms in terms of products or services provided. This situation may explain the weakened effect of relative attractiveness.

Second, perceived product quality and trust did not have a significant effect on CRC, and only the indirect effect through switching cost was verified. This finding differs from the results of Kim and Gupta [7], who found that trust had a direct effect on CRC. Nevertheless, these results do not imply that product quality and trust are not important, but suggest that users perceive these factors as antecedents to costs and benefits calculation. Hsu [71] suggested a value-based decision model in a switching context, demonstrating that factors, such as price, product quality, uncertainty, and loss of work, are antecedents to switching benefits and switching costs, influencing switching behavior. In the same context, the results of our study also suggest that perceived product quality and trust worked as antecedents to switching costs, with only an indirect effect on CRC.

Third, our study found that an overall negative attitude toward e-commerce services has an important effect on CRC. The results show that negative attitude has a relatively stronger effect on CRC than do switching costs and relative attractiveness. This finding indicates that a negative attitude toward a specific service may cause resistance to change, although other variables related to cost and benefit are also important. An interesting implication is that it is a strong precedent to negative WOM, along with resistance behavior.

Finally, it was found that while psychological risk and social risk have significant effects on negative attitude, privacy risk is not significantly correlated therewith. There are various interpretations regarding why privacy risk does not affect negative attitude. This result may be due to the fact that users do not focus much on this aspect as they enjoy various benefits through the exchange of private personal information. In addition, we have to consider that the sample of our study largely consists of young people, who can readily manage privacy issues in an e-commerce environment.

\subsection{Contributions}

This study has made several theoretical and practical contributions. From a theoretical perspective, it has expanded the existing theory explaining consumer resistance to change, and suggested a comprehensive research model that assesses user resistance behavior. The research model of our study provides a comprehensive understanding of user resistance behavior on rapidly increasing e-commerce platforms. Second, it has discovered the possibility of developing a parsimonious theory focusing on switching costs and switching benefits in understanding consumer resistance to change. The results of this study demonstrate that a decision on resistance is made based on the gap between cost and benefit, although there are various precedents related to user resistance behavior. Finally, the impact of negative attitude not only influences one's resistance behavior, but may also affect the resistance of other users. Few studies demonstrate the correlation between negative attitude and consumer resistance to change [31,51]. This study has contributed to the literature by investigating these relationships and establishing a theoretical framework of causality. 
Regarding practical implications, this study helps e-commerce companies understand the migration behavior of customers, which is a critical issue of the companies. Our research model explains why customers migrate to other e-commerce platforms and then reverse migrate to the previous platform. The reverse migration behaviors have not been discussed enough in existing studies, but this study innovatively approaches the issue and provides various insights. Second, our results showed that e-commerce platforms should exert great effort to induce positive attitudes among users through stable platform management. A negative attitude formed through risk perception is another factor that has a strong influence on consumer resistance to change, along with reasonable decision-making processes through cost and benefit calculations. Thus, e-commerce enterprises must work hard to eliminate various potential risks. Finally, negative attitudes may cause the spread of negative WOM. Therefore, e-commerce companies should try to eliminate psychological and social risk factors felt by users.

\subsection{Limitation and Further Study}

Although our study provides various implications, it also has some limitations. No major problems are expected to affect the generalization of our results because the use of e-commerce is active among young people. However, it would be meaningful if an empirical analysis is conducted to solve possible sample bias. Since only Chinese respondents participated in our study, it will be necessary to conduct research with e-commerce users in other countries in the future.

Author Contributions: Conceptualization, Methodology \& Writing-Original Draft Preparation, Y.C.; Writing review \& editing, S.F.W.; Writing - review \& editing, C.F.L.-S.; Data curation, Formal analysis, Funding acquisition \& Writing-Original Draft Preparation, H.L.

Funding: This work was supported by the Ministry of Education of the Republic of Korea and the National Research Foundation of Korea (NRF-2018S1A5A8027174).

Conflicts of Interest: The authors declare no conflict of interest.

\section{References}

1. Russell, J. Alibaba Smashes its Single's Day Record Once Again as Sales Cross \$25 Billion. Available online: https://techcrunch.com/2017/11/11/alibaba-smashes-its-singles-day-record/ (accessed on 17 July 2019).

2. JD.com. JD.com 6.18 Anniversary Sale Transaction Volume Reaches Record \$24.7 Billion. Available online: https://jdcorporateblog.com/jd-com-6-18-anniversary-sale-transaction-volume-reaches-record-247-billion/ (accessed on 17 July 2019).

3. Tmall, J.D. CIW China Online Retail Exceeded US\$593 bn in H1 2018. Available online: https://www. chinainternetwatch.com/26853/online-retail-h1-2018/ (accessed on 17 July 2019).

4. Shen, X. Pinduoduo Under Fire for Hosting Counterfeit Goods. Available online: https://www.abacusnews. com/big-guns/pinduoduo-under-fire-hosting-counterfeit-goods/article/2157617 (accessed on 17 July 2019).

5. Graziani, T. Pinduoduo: A Close Look at the Fastest Growing App in China. Available online: https: //www.techinasia.com/talk/pinduoduo-fastest-growing-app-china (accessed on 17 July 2019).

6. Kim, S.Y.; Chang, Y.; Wong, S.F.; Park, M.C. Customer Resistance to Churn in a Mature Mobile Telecommunications Market. Int. J. Mob. Commun. 2019, in press.

7. Kim, H.W.; Gupta, S. Investigating Customer Resistance to Change in Transaction Relationship with an I nternet Vendor. Psychol. Mark. 2012, 29, 257-269. [CrossRef]

8. Kim, M.K.; Park, M.C.; Jeong, D.H. The effects of customer satisfaction and switching barrier on customer loyalty in Korean mobile telecommunication services. Telecommun. Policy 2004, 28, 145-159. [CrossRef]

9. Kim, H.W.; Chan, H.C.; Lee, S.H. User resistance to software migration: The case on Linux. J. Database Manag. 2014, 25, 59-79. [CrossRef]

10. Kim, H.W.; Kankanhalli, A. Investigating user resistance to information systems implementation: A status quo bias perspective. MIS Q. 2009, 33, 567-582. [CrossRef]

11. Featherman, M.S.; Pavlou, P.A. Predicting e-services adoption: A perceived risk facets perspective. Int. J. Hum. Comput. Stud. 2003, 59, 451-474. [CrossRef] 
12. Liangyu China Ecommerce Market to Grow 19\% in 2017. Available online: http://english.gov.cn/news/top_ news/2017/06/23/content_281475695038849.htm (accessed on 17 July 2019).

13. Reuters China to Probe Ecommerce Firm Pinduoduo Over Reports of Fake Goods. Available online: https://www.reuters.com/article/us-pinduoduo/china-to-probe-e-commerce-firm-pinduoduo-overreports-of-fake-goods-idUSKBN1KM3FQ (accessed on 17 July 2019).

14. Zhao, R. Pinduoduo in Disputes with Store Owners After Quality Crackdown. Available online: https: //technode.com/2018/06/15/pinduoduo-dispute-store-owners/ (accessed on 17 July 2019).

15. Oreg, S. Resistance to change: Developing an individual differences measure. J. Appl. Psychol. 2003, 88, 680-693. [CrossRef]

16. Lacey, R. Relationship Drivers of Customer Commitment. J. Mark. Theory Pract. 2007, 15, 315-333. [CrossRef]

17. Samuelson, W.; Zeckhauser, R. Status quo bias in decision making. J. Risk Uncertain. 1988, 1, 7-59. [CrossRef]

18. Lee, M.C. Factors influencing the adoption of internet banking: An integration of TAM and TPB with perceived risk and perceived benefit. Electron. Commer. Res. Appl. 2009, 8, 130-141. [CrossRef]

19. Tandon, U.; Kiran, R.; Sah, A.N. The influence of website functionality, drivers and perceived risk on customer satisfaction in online shopping: An emerging economy case. Inf. Syst. E Bus. Manag. 2018, 16, 57-91. [CrossRef]

20. Hong, I.B.; Kim, T.; Cha, H.S. The mediating role of perceived risk in the relationships between enduring product involvement and trust expectation. Asia Pac. J. Inf. Syst. 2013, 23, 103-128. [CrossRef]

21. Yang, Y.; Liu, Y.; Li, H.; Yu, B. Understanding perceived risks in mobile payment acceptance. Ind. Manag. Data Syst. 2015, 115, 253-269. [CrossRef]

22. Peter, J.P.; Ryan, M.J. An investigation of perceived risk at the brand level. J. Mark. Res. 1976, 13, $184-188$. [CrossRef]

23. Cunningham, M.S. The Major Dimensions of Perceived Risk; Harvard University Press: Cambridge, MA, USA, 1967.

24. Cozzarin, B.P.; Dimitrov, S. Mobile commerce and device specific perceived risk. Electron. Commer. Res. 2016, 16, 335-354. [CrossRef]

25. Anderson, E.W. Customer satisfaction and word of mouth. J. Serv. Res. 1998, 1, 5-17. [CrossRef]

26. Hossain, M.; Jahan, N.; Fang, Y.; Hoque, S. Nexus of Electronic Word-Of-Mouth to Social Networking Sites: A Sustainable Chatter of New Digital Social Media. Sustainability 2019, 11, 759. [CrossRef]

27. Kim, Y.; Moon, H.S.; Kim, J.K. Analyzing the Effect of Electronic Word of Mouth on Low Involvement Products. Asia Pac. J. Inf. Syst. 2017, 27, 139-155. [CrossRef]

28. Hsu, L.C.; Chih, W.H.; Liou, D.K. Investigating community members' eWOM effects in Facebook fan page. Ind. Manag. Data Syst. 2016, 116, 978-1004. [CrossRef]

29. Lee, J.Y.; Park, J.H.; Jun, J.W. Brand Webtoon as Sustainable Advertising in Korean Consumers: A Focus on Hierarchical Relationships. Sustainability 2019, 11, 1364. [CrossRef]

30. Kim, T.T.; Kim, W.G.; Kim, H.B. The effects of perceived justice on recovery satisfaction, trust, word-of-mouth, and revisit intention in upscale hotels. Tour. Manag. 2009, 30, 51-62. [CrossRef]

31. Kim, Y.; Chang, Y.; Wong, S.F.; Park, M.C. Customer attribution of service failure and its impact in social commerce environment. Int. J. Electron. Cust. Relatsh. Manag. 2014, 8, 136-158. [CrossRef]

32. Wetzer, I.M.; Zeelenberg, M.; Pieters, R. "Never eat in that restaurant, I did!": Exploring why people engage in negative word-of-mouth communication. Psychol. Mark. 2007, 24, 661-680. [CrossRef]

33. Richins, M.L. Negative word-of-mouth by dissatisfied consumers: A pilot study. J. Mark. 1983, 47, 68-78. [CrossRef]

34. Zeelenberg, M.; Pieters, R. Beyond valence in customer dissatisfaction: A review and new findings on behavioral responses to regret and disappointment in failed services. J. Bus. Res. 2004, 57, 445-455. [CrossRef]

35. Konuk, F.A. The role of store image, perceived quality, trust and perceived value in predicting consumers' purchase intentions towards organic private label food. J. Retail. Consum. Serv. 2018, 43, 304-310. [CrossRef]

36. Flanagin, A.J.; Metzger, M.J.; Pure, R.; Markov, A.; Hartsell, E. Mitigating risk in ecommerce transactions: Perceptions of information credibility and the role of user-generated ratings in product quality and purchase intention. Electron. Commer. Res. 2014, 14, 1-23. [CrossRef]

37. Zeithaml, V.A. Consumer perceptions of price, quality, and value: A means-end model and synthesis of evidence. J. Mark. 1988, 52, 2-22. [CrossRef] 
38. Snoj, B.; Pisnik Korda, A.; Mumel, D. The relationships among perceived quality, perceived risk and perceived product value. J. Prod. Brand Manag. 2004, 13, 156-167. [CrossRef]

39. Frank, B.; Torrico, B.H.; Enkawa, T.; Schvaneveldt, S.J. Affect versus cognition in the chain from perceived quality to customer loyalty: The roles of product beliefs and experience. J. Retail. 2014, 90, 567-586. [CrossRef]

40. Han, J.; Kang, S.; Moon, T. An empirical study on perceived value and continuous intention to use of smart phone, and the moderating effect of personal innovativeness. Asia Pac. J. Inf. Syst. 2013, 23, 53-84. [CrossRef]

41. Moorman, C.; Zaltman, G.; Deshpande, R. Relationships between providers and users of market research: The dynamics of trust. J. Mark. Res. 1992, 29, 314-328. [CrossRef]

42. Spekman, R.E. Strategic supplier selection: Understanding long-term buyer relationships. Bus. Horiz. 1988, 31, 75-81. [CrossRef]

43. Tax, S.S.; Brown, S.W.; Chandrashekaran, M. Customer evaluations of service complaint experiences: Implications for relationship marketing. J. Mark. 1998, 62, 60-76. [CrossRef]

44. Urban, G.L.; Sultan, F.; Qualls, W.J. Placing trust at the center of your Internet strategy. Sloan Manag. Rev. 2000, 42, 39-48.

45. Song, H.; Ruan, W.; Park, Y. Effects of Service Quality, Corporate Image, and Customer Trust on the Corporate Reputation of Airlines. Sustainability 2019, 11, 3302. [CrossRef]

46. Chang, Y.; Wong, S.F.; Libaque-Saenz, C.F.; Lee, H. The role of privacy policy on consumers' perceived privacy. Gov. Inf. Q. 2018, 35, 445-459. [CrossRef]

47. Yang, H.; Lee, H. Exploring user acceptance of streaming media devices: An extended perspective of flow theory. Inf. Syst. E Bus. Manag. 2018, 16, 1-27. [CrossRef]

48. Liu, C.; Marchewka, J.T.; Lu, J.; Yu, C.S. Beyond concern-A privacy-trust-behavioral intention model of electronic commerce. Inf. Manag. 2005, 42, 289-304. [CrossRef]

49. Pavlou, P.A.; Fygenson, M. Understanding and predicting electronic commerce adoption: An extension of the theory of planned behavior. MIS Q. 2006, 30, 115-143. [CrossRef]

50. Burnham, T.A.; Frels, J.K.; Mahajan, V. Consumer switching costs: A typology, antecedents, and consequences. J. Acad. Mark. Sci. 2003, 31, 109-126. [CrossRef]

51. Kim, M.K.; Chang, Y.; Wong, S.F.; Park, M.C. The effect of perceived risks and switching barriers on the intention to use smartphones among non-adopters in Korea. Inf. Dev. 2015, 31, 258-269. [CrossRef]

52. Kim, T.; Yun, S. How Will Changes toward Pro-Environmental Behavior Play in Customers' Perceived Value of Environmental Concerns at Coffee Shops? Sustainability 2019, 11, 3816. [CrossRef]

53. Rogers, E.M. The Diffusion of Innovation, 5th ed.; Free Press: New York, NY, USA, 2003.

54. Li, Y.; Liu, H.; Lim, E.T.; Goh, J.M.; Yang, F.; Lee, M.K. Customer's reaction to cross-channel integration in omnichannel retailing: The mediating roles of retailer uncertainty, identity attractiveness, and switching costs. Decis. Support Syst. 2018, 109, 50-60. [CrossRef]

55. Pradhan, M.; Oh, J.; Lee, H. Understanding Travelers' Behavior for Sustainable Smart Tourism: A Technology Readiness Perspective. Sustainability 2018, 10, 4259. [CrossRef]

56. Littlejohn, S.W.; Foss, K.A. Theories of Human Communication; Waveland press: Long Grove, IL, USA, 2010.

57. Fishbein, M.; Ajzen, I. Attitudes towards objects as predictors of single and multiple behavioral criteria. Psychol. Rev. 1974, 81, 59-74. [CrossRef]

58. Ajzen, I.; Fishbein, M. Understanding Attitudes and Predicting Social Behaviour; Prentice-hall: Englewood Cliffs, NJ, USA, 1980.

59. Wangenheim, F.; Bayon, T. Satisfaction, loyalty and word of mouth within the customer base of a utility provider: Differences between stayers, switchers and referral switchers. J. Consum. Behav. Int. Res. Rev. 2004, 3, 211-220. [CrossRef]

60. Yang, H.; Lee, H. Understanding user behavior of virtual personal assistant devices. Inf. Syst. E Bus. Manag. 2019, in press. [CrossRef]

61. Wells, J.D.; Valacich, J.S.; Hess, T.J. What signal are you sending? How website quality influences perceptions of product quality and purchase intentions. MIS Q. 2011, 35, 373-396. [CrossRef]

62. Pritchard, M.P.; Havitz, M.E.; Howard, D.R. Analyzing the commitment-loyalty link in service contexts. J. Acad. Mark. Sci. 1999, 27, 333-348. [CrossRef]

63. Ha, Y.W.; Kim, J.; Libaque-Saenz, C.F.; Chang, Y.; Park, M.C. Use and gratifications of mobile SNSs: Facebook and KakaoTalk in Korea. Telemat. Inform. 2015, 32, 425-438. [CrossRef] 
64. Van de Ven, A.H.; Ferry, D.L. Measuring and Assessing Organizations; John Wiley \& Sons: Hoboken, NJ, USA, 1980.

65. Fornell, C.; Larcker, D.F. Evaluating structural equation models with unobservable variables and measurement error. J. Mark. Res. 1981, 18, 39-50. [CrossRef]

66. Henseler, J.; Hubona, G.; Ray, P.A. Using PLS path modeling in new technology research: Updated guidelines. Ind. Manag. Data Syst. 2016, 116, 2-20. [CrossRef]

67. Podsakoff, P.M.; MacKenzie, S.B.; Lee, J.Y.; Podsakoff, N.P. Common method biases in behavioral research: A critical review of the literature and recommended remedies. J. Appl. Psychol. 2003, 88, 879-903. [CrossRef]

68. Kock, N.; Lynn, G. Lateral collinearity and misleading results in variance-based SEM: An illustration and recommendations. J. Assoc. Inf. Syst. 2012, 13, 546-580. [CrossRef]

69. Tenenhaus, M.; Vinzi, V.E.; Chatelin, Y.M.; Lauro, C. PLS path modeling. Comput. Stat. Data Anal. 2005, 48, 159-205. [CrossRef]

70. Singh, J.; Sirdeshmukh, D. Agency and trust mechanisms in consumer satisfaction and loyalty judgments. J. Acad. Mark. Sci. 2000, 28, 150-167. [CrossRef]

71. Hsu, J.S.C. Understanding the role of satisfaction in the formation of perceived switching value. Decis. Support Syst. 2014, 59, 152-162. [CrossRef]

(C) 2019 by the authors. Licensee MDPI, Basel, Switzerland. This article is an open access article distributed under the terms and conditions of the Creative Commons Attribution (CC BY) license (http://creativecommons.org/licenses/by/4.0/). 